\title{
O Despertar da Cultura de Segurança: Um Olhar Multidisciplinar para os Desafios da Gestão de Riscos valorizando as Habilidades Não Técnicas
}

FERREIRA, Elizabete Cazzolato; ${ }^{1}$ MOREIRA, Valter Moreira da Cunha Daiello²; BANDEIRA, Adriana Ugoski ${ }^{3}$

\section{INTRODUÇÃO}

A gestão de riscos inclui o desenvolvimento de habilidades não técnicas. Tratam-se de competências comportamentais que otimizam a aplicação do conhecimento técnico de forma assertiva e profissional, em momentos de contingência.

\section{OBJETIVOS}

Descrever os desafios da cultura de segurança à luz das percepções de profissionais da aviação, enfermagem psicologia durante a implantação de um projeto de gestão de riscos com base em fatores humanos.

\section{METODOLOGIA}

Relato de experiência realizado a partir da análise observacional indireta de um programa de treinamento sobre gestão de riscos e cultura de segurança realizado no período de novembro de 2018 , com equipe multiprofissional de suporte assistencial em uma unidade hospitalar privada de grande porte da cidade de Vitória (ES).

\section{FUNDAMENTAÇÃO TEÓRICA}

Nossas tendências para agir sofrem influência direta da nossa experiência e cultura (GOLEMAN, 2011). As falhas humanas são as maiores causas de eventos adversos na área da saúde (HELMREICH; MERRIT, 2001) e, no contexto da segurança, destaca-se a importância de um direcionamento aperfeiçoamento contínuo dessa concepção, elevando a consciência situacional dos indivíduos para buscar a excelência e minimizar falhas e erros (REASON, 1990).

\section{RESULTADOS}

Após realização da abordagem conceitual, os participantes do programa de treinamento foram envolvidos em estratégias de avaliação de cenários e discussão crítica sobre diversos temas comportamentais. As habilidades não técnicas mais evidenciadas no desafio da cultura de segurança e identificadas dentro dos processos referenciais da aviação e das práticas médicas, sob a ótica da psicologia, foram: a comunicação e o relacionamento interpessoal.

\section{CONSIDERAÇÕES}

\section{FINAIS}

Vivenciar uma situação num contexto diferenciado, como o promovido no treinamento referido, levou o indivíduo à maior clareza e compreensão de suas práticas, o que, somado ao embasamento teórico, promoveu um outro sentido às suas ações, dando mais significado ao seu papel ativo na segurança e despertando o potencial transformador do ambiente ao qual se integra.

\section{REFERÊNCIAS BIBLIOGRÁFICAS}

GOLEMAN, D. Inteligência Emocional. Rio de Janeiro: Objetiva, 2011.

HELMREICH, RL; MERRIT, AC. Cultura no trabalho em aviação e medicina: Influências Nacionais, Organizacionais e Profissionais. 1a Edição. London: Routledge, 2001.

REASON, J. Human Error. New York: Cambridge University Press. 1990

1- Enfermeira, especialista em Terapia Intensiva, Master Coach e mestranda em Educação e Ciências em Saúde. Docente de Graduação em Enfermagem, instrutora do Curso SHCRM. Email: elizabete.cazzolato@gmail.com 